\title{
The State of Local Government
}

\author{
Purshottama Reddy
}

University of Kwazulu Natal, Durban, SAR

\author{
Juraj Nemec
}

Masaryk University, Brno, Czech Republic

\section{Michiel S de Vries}

Radboud University Nijmegen Institute of Management Research, Netherlands and Masaryk University, Brno, Czech Republic

cross $^{\text {ref }}$ http://dx.doi.org/10.5755/j01.ppaa.14.3.13430

Abstract. This paper and a special issue of the journal addresses the varying capacity of local governments in different regions in the world. Local Government Capacity as a concept can have varying definitions, but in this framework it seems adequate to simply define it as the ability of local government to perform their functions in an effective and efficient way'. The idea behind this special issue argues that in order to improve the capacity of local governments especially in regions where its adequate performance is severely needed, a more differentiated approach to capacity-building is required, pinpointing the main factors inhibiting local government performance.

Keywords: local government, local government capacity, service delivery, good governance.

Raktažodžiai: vietos valdžia, vietos valdžios gebèjimai, paslaugu teikimas, geras valdymas.

\section{Introduction}

This special issue is about the state of local government in varying regions all over the world. It addresses the varying capacity of local governments in different regions in the world. It is the result of a project that originated in 2011, when the United Nations Department of Economic and Social Affairs, Division for Public Administration and Development Management (UNDESA/DPADM) and the 
International Association of Institutes and Schools of Administration (IASIA) conducted a joint Ad Hoc Expert Group Meeting on "Strengthening Public Administration and Leadership for the Achievement of the Millennium Development Goals (MDGs) at Local Level" at the Faculty of Economics, Roma Tre University, Rome Italy.

The goal of the Taskforce was to contribute to the improvement of the performance of public administration and leadership at local level in implementing national and international development agenda. The project also intended to further improve the fit between the needs of local governments in terms of training, education, institution building in dealing with intergovernmental complexities and the products (training, education, institution building consultancy) offered by Universities, schools, and institutes of administration including MDIs.

One of the objectives of the Taskforce was to conduct a 'situation review' of public administration capacities at local level and provide an analysis of problems and challenges confronting local level public administration and leadership in light of the need to effectively implement national and international development agenda including the MDGs. The articles in this special issue give the needed information in that regard.

Local Government Capacity as a concept can have varying definitions, but in this framework it seems adequate to simply define it as 'the ability of local government to perform their functions in an effective and efficient way'.

In order to assess the capacity of local governments one therefore needs to have insight in their functions - what are they supposed to do? - and insight in their ability to perform these tasks. The prime focus of each article in this special issue therefore addresses the question whether local governments in the region the author focuses on, perform their functions in an effective and efficient way.

In fact, the actual functions of local government vary all over the world, especially with regard to the variety of policy areas they are responsible for. Nonetheless, one can distinguish two abstract dimensions which capture the basics of local government capacity. That is, service delivery and promoting good governance principles:

- On the one hand this is about what local governments are supposed to do, and whether they do this in an adequate effective and efficient way, that is, adequate service delivery in a varying area of policy-areas,

- Secondly, how local governments do it, especially with regard to principles of good governance, that is, transparency, accountability, rule of law, voice and democratic and accountable government, the involvement of communities and community organizations.

The main question relates to the main problems local governments encounter in different regions in the world causing inefficiencies and ineffectiveness in performing their tasks. 
In today's practice of trying to improve the functioning of local government, scholars and training institutes often tend to emphasize only one problematic aspect of local government, namely the issue of inadequate human resources as seen in the individual knowledge and skills of public officials and the inadequate management and leadership at the local level. This results in training programs that are often only aimed at improving management and leadership and which are supply-based and not always address the needs of local governments.

The idea behind this special issue argues that in order to improve the capacity of local governments especially in regions where its adequate performance is severely needed, a more differentiated approach to capacity-building is required, pinpointing the main factors inhibiting local government performance.

In the literature, one can find many factors explaining the varying capacity of local governments. The articles in this special issue distinguish four conditions, that is, contextual, structural, institutional and human resource conditions.

- Contextual conditions are found in the judicial situation, the socio-economic situation of the country involved, historical determinants, et cetera.

- Structural conditions refer to the position of local government vis-à-vis other governments, that is, for instance, the degree of decentralization, in terms of the delegation of tasks local government is responsible for, but also in terms of financial autonomy, that is, balanced decentralization in terms of input and output.

- Institutional conditions refer to the size of local government, its internal organization, its financial situation (budget), the availability of a robust database on key economic variables, personnel, financial management, and the quality of the infrastructure.

- Human resource conditions for instance refer to the quality of leadership, the availability of skills in economic and policy analysis, of skills in budgeting, financial management, procurement, well-trained staff for budgeting and personnel management, skills in auditing, survey design, and evaluation.

Next to regions on which much is known already, such as Europe, this special issue includes articles on the state of local government in regions which are until now hardly investigated, such as Central Asia, South Asia, Australasia, and Africa.

\section{Theoretical Foundations of Local Government Capacity ${ }^{1}$}

Capacity development in context and defining terms

\footnotetext{
1 The authors would like to acknowledge the contribution to this section by Roberta Ryan and Ronald Woods of the Australian Centre of Excellence for Local Government, University of Technology, Sydney
} 
The successful and ongoing development of any country is dependent to a large extent on having the required capacity to facilitate the process. Financial resources are imperative to fund development; however, without adequate supportive strategies; policy frameworks and legislation; procedures; skilled and educated people and effective and efficient public institutions, it is unlikely that the envisaged development can be achieved [12, p. 21]. These factors constitute the basic foundation for planning, implementation and reviewing local and national development strategies within the country. Capacity development seeks to sustain and more importantly strengthen this basic foundation and is in fact the "how" of ensuring that development can be more effective. This in turn leads to the quest for "capable institutions that is better able to achieve its mandate" [12, p. 21]. In developing this line of thinking further, it has to be pointed out that the MDGs/SDGs cannot be achieved by directing financial resources to developing countries, but the international development partners, governments, the non - governmental and private sector have to work collaboratively together in developing the capacities of countries to manage and utilize its resources available effectively and efficiently. Consequently, capacity development is a critical issue for all the key role-players and stakeholders involved in the attainment of the MDGs/SDGs and accordingly has to be accorded a high priority in this regard $[15$, p. $57 ; 10$, p. 1].

The concept capacity implies having the required aptitude, resources, relationships and facilitating conditions that are imperative to achieve some intended goals. Capacity is defined by the United Nations as "the ability of individuals, institutions and societies to perform functions, solve problems and set and achieve objectives in a sustainable manner" whilst the World Bank views it as "the ability to access and use knowledge and skills to perform a task and to act in pursuit of an objective" [15, p. 56]. Both these definitions emphasize that appropriate organizational structures, systems and resources have to be in place for public institutions to operate effectively, and more importantly staff have to have the ability to understand goals and objectives in order to deliver on pre - determined goals.

Capacity development as defined by the UN [13, p. 1] is the "process through which individuals, organizations and societies obtain, strengthen and maintain the capabilities to set and achieve their own development objectives over time". It is therefore the process through which the resources, systems, structures and abilities mentioned above are obtained, strengthened and adopted over a period of time [15, $\mathrm{p}$. 56]. More specifically, capacity development processes focuses on organizational change, leadership development, functional and technical capacities, policy changes, the enabling environment changing or even social cohesion which ensures that capacity can be used more effectively. Consequently, the work on capacity development would include inter alia, helping to diagnose capacity strengths, constraints and costs as well as supportive development strategies [14, p. 11]. The notion of capacity development thus extends beyond the concept training and includes: 
- Human resources development: individuals are equipped with the information, understanding; skills and training for effective performance;

- Organizational development: structures, processes and procedures being developed internally and externally (community, public and private sector);

- Legal and institutional framework: creating an enabling environment within the broader regulatory and public accountability framework for capacity development [15, p. 57].

Viewed in a much broader governmental context globally, capacity development is regarded as a society - wide transformation process which is driven locally and acknowledges and recognizes the fact that capable societies, organizations and public functionaries can play a critical role in enhancing public governance. Sustainable capacity at the national and local level is generally premised on inter alia, the following assumptions:

- local generated, owned and sustained capacity is key to the success of any local structures;

- development of technical capacities (engineering; accountancy and town planning) need to be complemented with leadership development, managerial capacity and performance enhancing measures; and

- enabling environment, notably strong political ownership and commitment to extensive participation, transparency and clear public accountability to ensure that capacity translates to practice [13, p. 2].

According to Honadle [5, p. 83], local government capacity refers to how the current 'factors of production' are being used at a point in time, and how they might be converted if there was the need to meet additional demands. These factors of production are dynamic and difficult to measure, often only making sense when compared to other places or the same locality at a different time. They include:

- Human resource capacity, based on the talent, intelligence, industry, educational background, commitment and experience of the councilors, staff and volunteers;

- The capacity to influence anticipated changes in the local government area (LGA), and ensure flexibility required for governing and making and implementing rational policy choices and learning from experiences; and

- Technical assistance, research and education, which provide indispensable tools for local governments to understand their current conditions, to learn about alternative policies and the likely consequences of their choices, and to make course corrections as they proceed with policy implementation $[5, \mathrm{p}$. 80-85].

Drawing on the international literature, Wallis and Dollery [17, p. 79] put forward a typology of local government capacity, incorporating four interlinked areas:

- Institutional capacity: local government's ability to uphold authority and regulation of economic and political interactions which are effective. This 
capacity is mainly derived from their relationship with higher tiers of government;

- Technical capacity: strategic direction and effective leadership to local organizations that can potentially facilitate socio - economic development;

- Administrative capacity: reflected through administering local infrastructure effectively and proven track record in terms of provision of public goods and services locally; and

- Political capacity: ability to engage different groupings in governance processes and facilitate activities in government and render services in response to local needs.

The move from 'local government' to 'local governance' has been a significant shift of late [4, p. 9], linked to trends such as increased urbanization, globalization and new substantive and participatory demands. Governance implies that local public decision-making has progressively involved policy networks, public partnerships and several agencies working collaboratively which transcends organizational boundaries. Local governments in a governance context are taking part in networks that 'they cannot easily steer, let alone dominate...[and]...the private sector, the local civil society and individual citizens have a much larger influence than before' [16, p. 551]. This suggests that the capacity for operating explicitly within a 'governance mode' has become a hallmark of modern local government. Networked governance have been evolving of late and several new forms relative to theory and practice have been introduced to replace the adversarial, narrow, hierarchical, and managerial modes that limit the ability of any one level of government, or any single stakeholder, to actively address the complex problems faced by communities [1, p. 16-8]. Governance is also collaborative, reflecting the growing interdependence amongst governments, nongovernment stakeholders and the community.

Carter [3, p. 2] provides a framework for considering 'five pillars of strength' that would ensure long term local government sustainability. This includes a structure strong in terms of ethical governance and the required authority to identify local problems and find local solutions; facilitating local economic development through community engagement and more specifically participation, communication, planning and leadership; a database and knowledge deemed strong supported with the requisite technological capacity to respond to community and business needs; skilled staff in terms of technology and community involvement; and long-term financial and asset management which is effective.

\section{The Link to Service Delivery and Good Governance}

Democratic governance is a system in which citizens participate in government planning and decision-making while those in office respond to citizen needs with accountability and transparency. If the system is successful, not only do citizens receive the services they are supposed to be provided by government, they also tend to trust the government and officials more [9, p. 3].The effective and efficient 
provision of municipal services is an integral part of good governance, as highlighted below. Service Delivery

Public institutions and more specifically municipalities are critical in terms of basic municipal service provision and infrastructural development. A variety of models of service delivery are utilised by national, provincial/state and local governments, public agencies and non-state actors [15, p. 42]. Globally, municipal service provision is viewed as a "service that a municipality in terms of its powers and functions provides or may provide to or for the benefit of its responsibility area irrespective of whether... such a service is provided, ... through an internal,... or, ...external mechanism" and whether "fees ... are levied in respect of such a service or not" [Craythorne as quoted by Nealer in 8, p. 94]. In this context, a basic municipal service can be viewed as "necessary to ensure an acceptable and reasonable quality of life and, if not provided would endanger public health or safety or the environment" [Craythorne in 8, p. 94]. There is general acceptance of what constitutes basic needs at the local level internationally and in this regard Bekink [2, p. 288] has pointed out that some of them are universally acknowledged and cites the examples of water, electricity; housing, solid waste disposal and general municipal infrastructure. Additional functions include education, transport, sporting and recreational facilities, public safety, human security, communication, information and registration (births, deaths, marriages and motor vehicles). These municipal services are provided to facilitate productive and reproductive activities of society and at the same time contribute to sustainable livelihoods, quality of life and human dignity [15, p. 42].

The majority of developing countries, following independence have undergone some sort of fundamental political and institutional restructuring process with a view to enhancing basic municipal service. However, in the majority of cases, despite decentralization policies being ushered in and considerable investments, both in terms of capital resources and time, local government performance has unfortunately not improved to the extent that the Millennium Development Goals (MDGs) and now the Sustainability Development Goals (SDGs) would have been satisfactorily addressed $[15$, p. $56 ; 10$, p. 2$]$. Issues of access to quality and adequate services, particularly those that have a direct bearing on the MDGs/SDGs are major challenges for particularly developing countries despite the different modalities of delivery. It was pointed out in the UN General Assembly High Level Plenary Meeting on the five year review of the Millennium Declaration held in September 2005 that public sector capacity was lagging behind all the other MDG indicators. Consequently, it is a fact that capacity development is a critical challenge faced by developing countries internationally $[13$, p. 1]. Some regions, entire cities, whole communities and individual households have limited or no access to basic services and consequently implies that particular segments of society are unable to have a decent lifestyle. The failure to provide basic municipal services impacts negatively on the attainment of the MDGs/SDGs and the national priorities of any country be it developed or developing. The situation in many developing countries, despite some variations nationally and sub - nationally has highlighted the fact that some municipal service related 
MDGs/SDGs are under threat as pointed out in several international reports [15, p. 42].

\section{Good Governance}

Good governance denotes the best process for formulating and implementing decisions in the public sector. Good decision-making processes and in the final analysis, good governance have several common characteristics, that does impact directly on local government namely equality; good working relationships and consultation. The key components of good governance are [18; OECD as quoted by 6 , p. 39]:

- Accountability: local government is accountable for its decisions as it is made on behalf of local communities;

- Transparency: how and when a decision is made should be clearly visible to the local citizenry;

- Rule of law: decisions are within the powers of council and consistent with relevant legislation /common law;

- Responsive: balancing competing interests timely, appropriately and responsively while addressing the needs of the entire citizenry;

- Inclusive and equitable: all groupings, more specifically those deemed the most vulnerable should be active participants in the process;

- Effective and efficient: implement decisions and follow policies that make the best use of the available people, resources and time to ensure the best possible results for their community; and

- Participatory: the local citizenry should be able to directly participate in the process or through recommendations.

Good governance is the "exercise of authority through political and institutional processes that are transparent and accountable and encourage public participation" $[11$, p. 1]. It necessitates pinpointing specific community values, reconciling varied interests, and developing a common understanding on "what is in the best interest of the whole community and how this can be achieved' [7, p. 33]. Human rights and good governance can be viewed as mutually supportive as the latter has certain distinct principles and values which guide the work of local governments and municipal functionaries. Democratic institutions introducing good governance reforms, where human rights values are critical considerations, provide mechanisms for the local communities to participate in policymaking either through consultations or submissions that are formal or informal. Good governance reforms in the broader context of service delivery tends to promote the notion of human rights when they enhance the capacity of the state to discharge certain basic services like inter alia, education, housing, health or food [11, p. 1]. Reform measures could include inter alia, strategies for public participation and decision-making; introduction of policies which are culturally sensitive with emphasis on services being acceptable and accessible and structures to ensure accountability and transparency. If the citizenry 
engages in decision-making processes meaningfully and inclusively, and if there is transparency and accountability on the side of government, the level of confidence in a democratic system of government increases and the positive spinoffs are stability and prosperity. [9, p. 3].The basic principles governing human rights makes provision for these basic and essential public services to be accessible, available and acceptable culturally thereby ensuring that the rights of the most indigent and marginalised are secured. In this context, good governance ensures that the participation of individuals and communities in question are secured as stakeholders rather than the beneficiaries of socio-economic development [11, p. 29].

\section{The Main Outcomes of the Articles in this Special Issue}

The articles included in this special issue describe and analyze the situation and capacities of local governments from very different perspectives. They intentionally cover relatively very developed area - Europe and Australia, but also regions with real challenges, like Central Asia or parts of Africa. In the following text we summarize main findings mainly on case by case principle.

Nemec and de Vries argue for Europe that the local government capacities and local government performance in Europe clearly rank this continent to the most developed world areas from the point of local democracy. The background factors explaining this situation have a multidimensional character and authors propose that the core positive factors are the relative economic wealth, high human development, the long historical tradition of the subsidiarity principle in most parts of Europe, and the regulatory function of the Council of Europe.

The strong development of local and regional democracy in Europe is protected and based on the principles of the Charter of the Council of Local and Regional Authorities of the Council of Europe, which, among its many activities, regularly organizes monitoring visits to all member states to check the situation of local and regional democracy. These visits are an important and effective tool to motivate all European governments to strengthen local democracy based on the principles of the Charter.

Authors also mention the core structural challenges, for instance the continuous discussion about amalgamation versus fragmentation, the overarching threat to the local democracy in Europe today - the financial crisis, which significantly decreased the level of available financial resources for self-governments, while the structure of responsibilities remains the same or even increases and the demands certainly increase and existing trends toward re-centralization or limited real will do continue with decentralization in, both in established and emerging democracies.

Regional issues in Europe differ - authors argue that the core issue might be the situation of post-communist countries, where local democracy does not have a long tradition and still needs to be revitalized. Moreover, in some CIS countries central governments are not at all inclined to promote the idea of decentralization as the official national policy (especially Belarus and very much also Azerbaijan). 
The paper by Urinboyev explores the context, problems, quality, and challenges of local governance in four Central Asian countries: Kazakhstan, Kyrgyzstan, Tajikistan, and Uzbekistan. The prime focus is on the question of whether local governments in this region perform their functions in an effective and efficient way. The findings indicate that local governments in Central Asia do not have real capacity to adequately address the needs and concerns of citizens - contextual, structural, institutional and human resource capacities, and they are heavily dependent on the central government in all policy issues, be it taxation, service delivery, local development, or privatization.

A crucial lesson emphasized by the author is the fact that the socio-political context of Central Asia largely differs from the Western one and that administrative reform initiatives produce rather different outcomes. Decentralization in Central Asia largely takes on the form of a geographically based struggle between state elites for control over access to resources. These regional power structures are less concerned with local development issues and are more inclined to seek rent. In such a situation there is hardly any evidence that local government reforms could be beneficial and would increase the quality of public services: likewise, further decentralization only serves to intensify the struggle among governing elites for control over sphere of influence.

The author also argues that the core challenge hindering local government reform comes from the persistence of authoritarian style administrative practices. Although there have been some local government reform initiatives in the region, but they remained 'in paper' and had little or no effect on governance processes in the region and, while in practice local government continue to be subordinated to central government in all public policy issues, be it education sector, taxation, health care, welfare or agriculture.

Ryan and Woods argue for Australia that the local government sector's position in the Australian Federation still remains weak. Local government's primary relationship remains with the states, and there has been no concerted policy direction in recent years to devolve greater levels of responsibility for policy making, management, financial autonomy and implementation of national goals to the third tier of government.

The authors argue that the potential gap between expectations and resourcing to carry out necessary functions remains one of the prime concerns with regard to local government capacity in Australia. The workforce is highly educated on the whole, but there are skills shortages in key areas and the sector is facing problems with the aging of the workforce. Local governments in Australia exhibit considerable diversity, and there are different opportunities and challenges for metropolitan and other urban municipalities compared to local governments in regional, rural and remote areas. In many rural and remote communities, local government is a major employer, the primary economic driver and the only level of government delivering basic social and community services. 
Capacities of local governments in Australia have recently been enhanced by focusing on effective long-term financial and asset management, a renewed emphasis on strategic planning and performance reporting, and structural reforms, which include mechanisms such as closer collaboration amongst local governments, shared service arrangements, boundary changes and mergers.

Concerning future challenges the authors argue that there is growing acceptance in the local government sector that enhanced strategic capacity linked to factors such as increased size and resourcing levels, pooling of knowledge and expertise, and encouraging a focus on operating in a broader context appears essential to local government's long-term success as a valued partner in the federal system of government. Capacity-building requires a skill set and enhanced capabilities at both local political and administrative levels, underpinned by greater levels of collaboration within the sector, and a consistent focus on being strategic enablers for local communities. In order to set the agenda and facilitate local solutions to local problems, there is a need to retain and attract a flexible and multi-skilled workforce that is informed by the multi-faceted community which it serves. Leadership and management capacity is crucial in this regard and, in this quest for enhanced capacity, local government as a sector is supported by national and state-based local government associations, an established and continuously improving tradition of research and reporting, and a growing emphasis on education and training for both elected local politicians and for local government personnel.

In the next article about South Asia, Basu first introduces the very interesting point that decentralization in the region is a sine-qua-non for the eradication of poverty and hunger in this region and this is why decentralization processes progress step by step in South Asia. However, he also suggests that a lot needs to be done to increase local government capacities in the region and proposes four concrete core challenges.

First, it is essential to have a strong political commitment for decentralized governance. This is to be followed by strong and clear legislative implementation of demarcation of role and function between central line ministries, local bodies, civil society organizations as well as different layers of local bodies and other stakeholders including NGOs.

Second, fiscal federalism system should be created - like the legislative provisions for inter-governmental transfers like sharing of revenue and tax proceeds; common property resources and borrowing by local bodies from financial institutions need priority attention. Streamlining budget spending processes and procedures and enhancing local revenue mobilization can help to solve situations when the actual demand for physical and social infrastructure at the local level far exceeds the availability of financial resources from local tax and non-tax income as well as the annual grants from the government.

Third, effective service delivery systems shall be established - this requires central, provincial and local actions such as promoting transparency, mechanisms of 
accountability, and citizens' voice; improving incentives for performance; and building systems to monitor outcomes and support capacity building.

Fourth, capacity building measures for local bodies are of paramount importance to make these institutions self-sufficient, efficient and effective. Capacity building initiatives include establishment of systems - manuals, guidelines, direction, networking and partnership, openness and transparency, timely dissemination of information, right to access information through the use of information technology, and human resource development. The blurred line between elected representatives and officers is again something which needs to find convergence. Further, to ensure capacity building at organizational and human levels, it is important to build up a dedicated cadre for local government having the requisite skill and aptitude.

The final lesson is that South Asia is in midst of transition and reforms for democratic decentralization are in progress. The road is long and tortuous, but it is the only 'one-way' path to alleviation of poverty, inclusive growth, participatory planning and providing equality and justice to the people.

Mutahaba and Pastory argue that recent decentralization reforms in East Africa are relatively ingrained with the vigor to strengthen local governments, but face many serious challenges. The service provision capacity of local governments is largely affected by the power status of local government - local governments remain weak in terms of decision making, human resource management and fiscal autonomies.

The lack of reliable and sufficient finances as well as qualified and adequate service delivery professionals continues to be a serious challenge facing local governments in East Africa. This has negatively impacted on their capacity to deliver services. Local government's adequacy and reliability of finances are overdependent on central government which finances over $90 \%$ of their budget. Coupled with budget deficits, arising from poor economies, and discretionary power of central government on budget matters, shortages and unreliable financing of local governments are to be expected. This implies that without efficient country economic performance as well as an enlarged local government's own resource base, the financing of local government will continue to be a challenge.

The underdeveloped nature of most rural areas in the region contributes to the limited human resource capacity at the local level. Compared to urban areas, the many rural councils are relatively underdeveloped in terms of capacity to build infrastructure such as roads, electricity and housing. This has impacted negatively on their possibilities to attract and retain qualified personnel, especially in scarce professions such as health. Therefore, building capacities of local government would also imply rural transformation.

In the last paper, Reddy and Kauzya present the situation in the Southern African Development Community Region mainly from the point of the progress made in attaining the Millennium Development Goals, progress in service delivery and revenue mobilization. They argue that it is quite apparent that the overall enhancement of the local government system progress has contributed to reaching some of the targets set for the MDGs for 2015. However, the general performance of 
local government in the Region can be summarized as mixed and inadequate. The core challenges analyzed in this paper are connected with fiscal decentralization, service delivery and human resources.

The distinct challenges related to local government financing in the Region are due to a mixture of causes found in the extent of fiscal decentralization and powers; the fact that there are very few local resources; the failure to maximize revenue collection; the increasing reliance on central/local fiscal transfers; inconsistency in fiscal transfers which can be quite unpredictable; lack of sustainability and donor dependence, lack of strategic engagement with the private sector and limited accountability and transparency.

From the point of view of service delivery the authors indicate considerable disparities relative to performance and progress across the Region and it is generally accepted that the higher income communities tend to have much better access to public services. Distinct challenges in relation to education; health; water and sanitation have compounded the problems of marginalized groupings.

The fact that a significant number of local governments cannot even discharge their traditional functions is connected also with limited human resources capacities and their motivation - for example only eight percent of public servants in Mozambique have university education.

At the end the authors argue that coping with existing challenges, especially the countries' political will constitutes a major challenge in terms of moving towards the MDGs and improving the local government performance.

\section{Conclusions}

1. The articles in this special issue point to a huge variance in the state of local government all over the world. If one thing stands out in this special issue, it is that issues and challenges at the local level need to be contextualized, within the intergovernmental relations between central, regional and local government and within the socio-economic and political context of regions. If service delivery at the local level hampers, it is mostly not local government that is to blame, but more often the bad intergovernmental, socio-economic and political conditions under which local governments have to function.

2. As to intergovernmental relations it is seen that regions differ in the extent to which local governments are dependent on central governments for their revenues and discretionary powers. The transfers from the central level are not always stable, partly because of rent-seeking behavior of national and regional elites and partly because of financial problems in the public sector as a whole. At present, the intergovernmental relations in many regions are to a larger extent characterized by a transfer of the financial crisis of the central to the local level than by a transfer of sufficient revenues in that direction. Sometimes this is caused by the lack of political will at the center to transfer authority and powers to the local level, at other times it is caused by real national budget deficits. A major impediment to adequate service delivery at the local level is therefore found in the lacking capacity of local governments to create their 
own revenues and the unwillingness/impossibility for national elites to let local governments create their own revenues. The both factors inhibit local government capacity to deliver services. No matter what the cause in specific regions, all in all we see a relatively weak local government system all over the world.

3. This brings national governments in some regions to the inclination to recentralize, if not the implementation of service delivery, than at least the policydevelopment process, the the definition of boundary conditions and the subsequent regulations which limit local governments in their policy discretion because local governments have to provide services within those institutional settings.

4. Although most if not all authors in this special issue would favor further decentralization, especially fiscal decentralization - perhaps going hand in hand with an increased size of local government - the articles in this special issue also show that decentralization in itself does not automatically improve the situation as local governments may lack decision-making capacities, technical know-how and are often unable to attract qualified personnel. Even in a well-developed country as Australia there are shortages in such qualified personnel at the local level in key-areas, let alone in developmental regions such as in Asia and Africa.

5. If decentralization of powers and authority is to fulfill its promises - that is more effectiveness, more efficiency, policy-learning through diversity, increased public participation, the possibility of tailor-made policies, being closer to the people and thus inducing more responsiveness to local needs, less bureaucratization and regulation, and policies being based on specific knowledge of local circumstances - it is not enough to just transfer the responsibilities. Such processes need to be accompanied by actions that create the potentiality of local governments to achieve these aims. This is to be done primarily by capacity-building not only at the individual, structural, institutional or contextual level, but a capacity-building that incorporates each of these factors. Just giving courses in leadership and management does not do the job and neither does a training on building institutions alone, if factors and actors in the context are adversary to change. Such capacity building is in need of a combined effort to create favorable conditions in all four aspects of local capacity. Capacity building needs to ensure that qualified personnel is available and can be attracted by local governments. This can be done by training public officials at the local level, based on the needs in key areas addressing the challenges local governments face and analyze the way they match the problems, challenges, and capacity shortfalls of public administration and leadership at local level. But capacitybuilding is also needed to alter intergovernmental relations, to create the needed institutions and to create a structure enabling instead of inhibiting local governments to deliver services which are appreciated by the public, which are indeed effective and also in other aspects fulfill the promises of decentralization.

6. This topic is our next research project. To investigate to what extent capacitybuilding by universities, school, and institutes of Administration, by international organizations as well as regional organizations take up that challenge. In the end this has to result in the provision of guidelines and tools that support public administration 
and leadership to assess their capacities and devise means of addressing capacity shortfalls, to make recommendations on how to strengthen public administration and leadership capacities at the local level, to provide, training programs/modules that respond to the identified local level public administration and leadership capacity development needs.

\section{References}

1. Abbot, J. (2013). Collaborative Governance and Metropolitan Planning in South East Queensland - 1990 to 2010: From a Voluntary to a Statutory Model. ACELG. Sydney: University of Technology, Sydney.

2. Bekink, B. (2006). Principles of South African Local Government Law. Durban: LexisNexis/Butterworths.

3. Carter, M. (2013). Briefing Paper: Australian local government financial reform - A federal perspective. Canberra: ANZSOG Institute of Governance and ACELG. Sydney: University of Technology.

4. Denters, B. and Rose, L.E. (2005). Local governance in the Third Millennium: A brave new world? In: B. Denters and L.E. Rose [Eds.]. Comparing Local Governance: Trends and Developments. Houndmills, Basingstoke, UK: Palgrave Macmillan, 1-13.

5. Honadle, B.W. (2001). Theoretical and practical issues of local government capacity in an era of devolution. The Journal of Regional Analysis and Policy, 31(1): 77-90.

6. Pillay, S; Reddy, P.S and Mohamed Sayeed, C.(2015).The South African Local Government system and the Study of Public Administration. in Quo Vadis: Local Governance and Development in South Africa Post 1994. P.S. Reddy and M De Vries (eds.). Belgium: Bruylant Publsihers

7. Pillora, S. and McKinlay, P. (2011). Evolution in Community Governance: Building on What Works, Volume 2, Literature Review. Sydney: ACELG, University of Technology.

8. Reddy, P and Naidu, R. (2012). Development and Local Government: The South African Experience in Local Government: A Global Perspective. B S Baviskar and A N Roy (eds.). New Delhi: Government of India

9. Transparency International Slovakia/Slovak Governance Institute. undated. Good Governance in Local Government. Slovakia: International Republican Institute.

10. United Nations Capital Development Fund. (2007). Delivering the Goods: Building Local Government Capacity to Achieve the MDGs. New York

11. United Nations. (2007). Good Governance Practices for the Protection of Human Rights. New York/Geneva: Office of the UN High Commission for Human Rights.

12. United Nations. (2010a). Supporting Capacity Development: The UNDP Approach. New York: UNDP.

13. United Nations. (2010b). Capacity Development for Disaster Risk Reduction. Bureau for Crisis Prevention and Recovery. New York: UNDP. October

14. United Nations. (2010c). Capacity Development in Post Conflict Countries: Global Event Working Paper. New York: UNDP. 
15. United Nations. (2012). Local Governments in Southern Africa: An Analytical Study of Decentralisation, Financing, Service Delivery and Capacities. New York: UNDP.

16. Van den Dool, L., van Hulst, M. and Schaap, L. (2010). More than a friendly visit: A new strategy for improving local governing capacity. Local Government Studies, 36(4): 551568.

17. Wallis, J. and Dollery, B. (2002). Social capital and local government capacity. Australian Journal of Public Administration, 61(3): 76-85.

18. http://www.goodgovernance.org.au/about-good-governance/what-is-good-governance/

Purshottama Reddy, Juraj Nemec, Michiel S de Vries

\section{Vietos valdžios būklè}

Anotacija

Šis straipsnis ir visas specialus žurnalo numeris skirtas vietos valdžios gebejjimų ịvairovei skirtinguose pasaulio regionuose analizuoti. Vietos valdžios gebèjimai kaip koncepcija gali turèti ịvairius apibrèžimus, bet šio leidinio kontekste yra geriausia juos apibrěžti paprastai kaip“vietos valdžios gebejjimą igyvendinti savo funkcijas veiksmingai ir efektyviai“. Svarbiausia šio specialaus numerio ideja yra tame, kad siekiant pagerinti vietos valdžių gebejjimus ypatingai regionuose, kur adekvatus jos veiklumas yra itin reikalingas, yra būtina labiau diferencijuota prieiga ị gebèjimų vystymą, tiksliai pabrèžiant svarbiausius vietos valdžios veiklumą varžančius veiksnius.

Purshottama Reddy - Professor at the University of Kwazulu Natal, Durban E-mail.: reddyp1@ukzn.ac.za

Juraj Nemec - Professor, Dr. at the Department of Public Economics, Faculty of ecomonics and Administration, Masaryk University, Brno,Czech Republic E-mail.: Juraj.Nemec@econ.muni.cz

Michiel $S$ de Vries - Michiel $S$ de Vries - holds the chair in Public Administration at the Radboud University of Nijmegen and is visiting professor at the Masaryk University; President of the International Association of Schools and Institutes of Administration (IASIA)

E-mail.: m.devries@fm.ru.nl

Purshottama S. Reddy - Kwazulu Natal universiteto profesorius (Durbanas, PAR) E.paštas: reddyp1@ukzn.ac.za

Juraj Nemec - Masaryko universiteto Ekonomikos ir administravimo fakulteto Viešososios ekonomikos katedros profesorius.

E.paštas: Juraj.Nemec@econ.muni.cz

Michiel $S$ de Vries - Radboud Nijmegeno universiteto Nijmegen Viešojo administravimo katedros vedejjas, Masaryko universiteto vizituojantis profesorius, Tarptautinès administravimo mokyklų ir institutų asociacijos (IASIA) prezidentas.

E.paštas: m.devries@fm.ru.nl 
Straipsnis įteiktas redakcijai 2015 m. rugpjūčio mèn.; recenzuotas; parengtas spaudai $2015 \mathrm{~m}$. rugsèjo mèn. 